TIBOR TÓTH

https://orcid.org/0000-0001-7778-9474

National Disability and Social Politics Centre, Budapest

\title{
LESSONS FROM THE GREAT DEPRESSION \\ IN HUNGARY. THE IDEA OF 'CHRISTIAN AGRICULTURE' AND ITS LIMITS
}

Zarys treści: Na Węgrzech Wielki Kryzys najbardziej dotkliwy i najdłużej utrzymujący się wpływ wywarł na sektor rolniczy. Niniejszy artykuł skupia się na działaniach podjętych przez rząd Gyuli Gömbösa, sprawujący władzę w latach 1932-1936. Po podjęciu natychmiastowych kroków w celu opanowania kryzysu Gömbös i jego poplecznicy starali się prowadzić długofalową politykę rolną i społeczna, opierając się na idei „chrześcijańskiego rolnictwa”. W ich rozumieniu oznaczało to reorganizację gospodarki kraju i nadanie pierwszoplanowej roli sektorowi rolniczemu, ponieważ to właśnie chłopi mieli być według rządu gwarantem funkcjonowania państwa. W artykule opisano koncepcję „chrześcijańskiego rolnictwa” jako alternatywnego sposobu wyjścia z kryzysu, przeprowadzono również analizę procesu wdrażania tej polityki i omówiono jej główne ograniczenia.

The content outline: In Hungary, the effects of the Great Depression were the most serious and long lasting in the agrarian sector. The present paper focuses on the actions of the Gömbös government, which ruled Hungary between 1932 and 1936. After taking immediate crisis management actions, Gömbös and his followers tried to base their long-term agrarian and social policy on the idea of 'Christian agriculture.' It meant, according to their views, that the economy of Hungary should be reorganized in an agrarian way as the Hungarians who keep the nation alive are the peasants. This paper not only describes the concept of 'Christian agriculture' as an alternative way out of the Depression, but analyses the process of the policy's execution and refers to its limits.

Słowa kluczowe: Węgry, Wielki Kryzys, Gyula Gömbös, „chrześcijańskie rolnictwo", chłopi, rewizjonizm

Keywords: Hungary, Great Depression, Gyula Gömbös, 'Christian agriculture', peasants, revisionism 
In the wake of the outbreak of the world crisis in 2008, an increasing interest in earlier crises of the world economy could be observed, among which the greatest attention has been paid to the Great Depression, which broke out in 1929. Historiographic overviews show that "there is no other topic in the history of economy or in macroeconomics which has sparked such a keen interest." In Central and Eastern Europe, the works written on this branch of economics have dealt in detail with the connection of the Great Depression and agriculture. It is understandable, as at that time agriculture was the primary sector of economy in terms of both the GDP and employment. ${ }^{2}$ Numerous analyses can be found on the effect the Depression had on the evolution of agricultural prices and selling possibilities, the situation of particular sectors, the governmental policies applied etc. Nevertheless, researchers have showed little interest in what conclusions were drawn by the governments and agrarian producers from the Depression and how this influenced them in the subsequent periods. This issue deserves further investigation as it also influenced later agrarian development, whether a given country addressed only the crisis of overproduction or perhaps also the structural problems of the sector.

The present study is focused on the actions of the government which ruled Hungary between 1932 and 1936, both during the Depression and in its aftermath. The Prime Minister, Gyula Gömbös, introduced noticeable initiatives in the agrarian policy after the crisis declined, in 1935-36. The case of Hungary deserves attention as the proportion of large estates in the country was the highest in Europe. This feature has special relevance to Polish readers, too. Whereas interwar Western Europe was dominated by family farms, Hungary was characterized by agriculture with a dual structure of land ownership. About half of the area of land belonged to a few owners, whereas the other half of the land was divided among millions of unsustainable peasant holdings. The first part of this paper will therefore investigate the effects of the Great Depression in this dual agriculture. The second part will describe the concept of the so-called 'Christian agriculture' as an alternative way out of the Depression. The third part will analyse the process of the policy's execution. All this requires a complex method of investigation combining the analytical aspects of political, economic and social history.

1 Á. Pogány, “A nagy válság nagy magyarázatai. Az 1930-as évek gazdasági válsága az újabb szakirodalom tükrében,” Korall 14, 2013, no. 54, p. 153.

${ }^{2}$ I.T. Berend, G. Ránki, Economic Development in East-Central Europe in the $19^{\text {th }}$ and $20^{\text {th }}$ Centuries, New York and London, 1974, pp. 306-307. 


\section{The effects of the Great Depression on Hungary's dual agriculture}

To give a brief historical context, one has to go back as far as the abolition of serfdom. After 1848, the Hungarian aristocracy was strong enough to hinder the peasant population in receiving amounts of land in proportion to their numbers, so the serf emancipation left most peasants without land or only with small plots. Approximately half of the land remained in the hands of the landowners. ${ }^{3}$ The loss of free serf labor forced large landowners to convert their estates into capitalist management. The landless strata found jobs mainly on large estates, and the opportunities offered by such properties determined their living conditions. Aside from sustaining the large estate system, numerous smaller feudal constraints also remained in force, which hindered the advancement of capitalist development. ${ }^{4}$

In the beginning of the twentieth century, Hungary was part of the Austro-Hungarian Monarchy. Following the end of World War I, supported by revolutions, this dualistic state disintegrated. The process culminated in the Trianon Peace Treaty of 1920, which deprived Hungary of two-thirds of its former territory and nearly $60 \%$ of its population, including $30 \%$ of ethnic Hungarians. ${ }^{5}$ In an atmosphere burdened by the experience of a lost war and two crushed revolutions in 1918-1919, the country was taken by experienced politicians and magnates who wanted to restore the pre-1914 relations of power. Hungary remained a monarchy, though one presided over by a regent, Admiral Miklós Horthy. In the period between 1920 and 1931, two prime ministers - Count Pál Peleki (1920-21) and Count István Bethlen (1921-1931) - played an important role. " "The post-war events led them to the conclusion that liberalism had to be controlled, and they argued that Central and Eastern Europe, including Hungary, was as yet too

${ }^{3}$ I. Orosz, "Peasant Emancipation and After-Effects," in: Hungarian Agrarian Society from the Emancipation of Serfs (1848) to the Re-Privatization of Land (1998), ed. P. Gunst, New York, 1998, pp. 53-59.

4 The most important of these feudal constraints was the extension of the already existing institution of entailed property. Between 1870-1900, 64 new entailed estates were created; their area increased five-fold. The area of other lands, the sale of which had been banned or restricted, also increased considerably; ibid., pp. 90-91.

${ }^{5}$ I.T. Berend, G. Ránki, "The Economic Problems of the Danube Region after the Breakup of the Austro-Hungarian Monarchy," in: Trianon and East Central Europe. Antecedents and Repercussions, eds. B.K. Király, L. Veszprémy, New York, 1995, pp. 149-163.

${ }^{6}$ I. Romsics, Hungary in the Twentieth Century, Budapest, 1999, pp. 181-185. 
immature to graft democracy on the parliamentary system, which they nevertheless considered the only acceptable form of government. Teleki and Bethlen therefore advocated a 'conservative democracy,' guided by the aristocracy and the landed nobility, as the proper response of the region to the challenges of the democratic age."”

It has to be emphasized that traditional aristocracy was able to mostly retain its power in the new political arrangement after the Trianon Peace Treaty. It could be observed in the fact that whereas major land reforms were introduced across Europe after World War I, ${ }^{8}$ in Hungary the aristocracy managed to keep its earlier positions in the structure of land ownership. Even the great land owners learnt from the experiences of the revolutions and saw that peasants would not be appeased without any distribution of land, although they wanted to keep the area of land to be distributed to a minimum. ${ }^{9}$ When they felt that the Allied Powers were treating them as partners, they started to increasingly oppose any radical changes in the land property system. Peasantry was treated as a class demanding leadership and guidance. Although the United Agrarian Laborers' and Smallholders' Party representing the peasant society won the elections in 1920, they were not able to pass their radical land reform program in the face of opposition from traditional elite groups. The law announced on 7 December 1920 resulted in a modest and sluggish land reform. However, the Hungarian land reform left the predomination of large estates untouched. Nearly half of the country's arable land was owned by a few dozen aristocratic families, yet the proportion of non-aristocratic large estates was high. ${ }^{10}$ Moreover, Bethlen amalgamated the United Agrarian Laborers'

${ }^{7}$ L. Kontler, A History of Hungary, New York, 2002, pp. 345-346.

8 The most radical land reforms were introduced in Central and Eastern Europe, where the former empires disintegrated and the central power became weaker. However, the wave of land reforms after World War I reached countries as distant as England, Wales and Scotland, where government programs helped tenants purchase the lands they worked. It is also interesting to mention Denmark, which had already become a country of family farms back in the nineteenth century. Nevertheless, in 1919 the government considered it necessary to pass a law on the purchase of a part of the entail estates, thereby facilitating the formation of new family farms. P. Brassley, "Land Reform and Reallocation in Interwar Europe," in: Contexts of Property in Europe. The Social Embeddedness of Property Rights in Land in Historical Perspective, eds. R. Congost, R. Santos, Turnhut, 2010, pp. 145-164.

${ }^{9}$ L. Püski, "Az agrárkérdés a harmincas évek Magyarországán nagybirtokos nézôpontból," in: Politika, gazdaság és társadalom a XX. századi magyar történelemben, ed. L. Püski, L. Timár, T. Valuch, Debrecen, 1999, pp. 115-122.

10 J. Sipos, "A földkérdés," in: Gróf Bethlen István és kora, ed. I. Romsics, Budapest, 2014, pp. 109-120. 
and Smallholders' Party with the aim to create a powerful government party, so the peasant society lost its direct representative institution. ${ }^{11}$

Another heavy burden on the economy was the fact that large and middle-size estate owners did not introduce considerable changes in their production structures and carried on growing mainly crops (first of all wheat), which were sold abroad. This way, growing crops not only remained a characteristic feature of Hungarian agriculture, but it became even more prominent. ${ }^{12}$ A mild upturn in the second half of the 1920s shrouded these unsolved problems, so the structural weaknesses of this sector became visible only after $1929 .{ }^{13}$ The Hungarian agricultural products were purchased on the former export markets despite these countries' efforts towards self-sufficiency. The majority of Hungarian exports were directed at Austria and Czechoslovakia. ${ }^{14}$

In the meantime, signs of overproduction were to be seen in Europe. This phenomenon could be explained by the fact that Europe was flooded with cheap overseas agrarian products, and it became more and more difficult to find markets for Hungarian agricultural export. Even if such markets were found, Hungarian products had to be sold at lower prices than earlier. Therefore, the agrarian crisis affected both sales and prices. It is important to note that the decline of agrarian export became a serious problem of external trade and therefore an issue of the state budget in Hungary, affecting the whole economy. ${ }^{15}$

In the beginning, the Bethlen government tried to make up for the losses resulting from price reduction by introducing the so-called boletta system in 1930. After calculating the sold quantities of wheat and rye, a price compensation was paid by the state; obviously, mainly the big landowners benefitted from the scheme. ${ }^{16}$ It is not surprising, as this

11 The name of the government party: the Christian National Unity Party, which up until 1932 was usually mentioned in a shorter form as the Unity Party. The party won $58 \%$ of National Assembly seats in the 1922 election and 69\% in 1926.

${ }_{12}$ M. Kopsidis, "Agricultural Development and Impeded Growth: The Case of Hungary, 1870-1973," in: Agriculture and Economic Development in Europe since 1870, ed. P. Lains, V. Pinilla, London and New York, 2009, pp. 286-310.

13 J.Held, "The Interwar Years and Agrarian Change," in: The Modernization of Agriculture: Rural Transformation in Hungary, 1848-1975, New York, 1980, pp. 216-223.

${ }^{14}$ Between 1925 and 1928 , close to $80 \%$ of corn crops, $78 \%$ of wheat comprising close to half of the grain exports, $85 \%$ of flour, $77 \%$ of homed cattle and $99 \%$ of hog exports; A trianoni Magyarország mezógazdasága, vol. 2, pp. 525-526.

${ }_{15}$ The case of Hungary within a Central and Eastern European context is discussed in: I.T. Berend, G. Ránki, Economic Development..., pp. 242-284; M. Kopsidis, op. cit., pp. $286-310$.

${ }_{16}$ Article XXII of 1930 (the so-called boletta act) provided for the measures needed to be taken to sell crops. According to the act, wheat and rye could only be sold with 
group had the most powerful lobby, which could enforce their interests among agrarian producers. ${ }^{17}$

These early measures brought about a serious political crisis in the governing party (Unity Party) led by Count István Bethlen. The conflict resulted in the secession of the groups who felt that the government neglected the interests of peasant farms compared to the interests of the great landowners. This way, the Independent Smallholders' Party (in Hungarian: Független Kisgazdapárt) was established in late 1930. ${ }^{18}$ The Smallholders' Party built its organisations very quickly all across the country and in the meantime, it grew to become a significant opposition party. Its foundation meant that peasantry once again gained its independent political organisation and representation. The elections of 28-29 June 1931 were even more telling. Although the governing party retained absolute majority (64\%), it became the 'loser' of the elections: it was able to keep only 158 of its former 170 seats. ${ }^{19} \mathrm{In}$ less than a month, the Bethlen government, which had been governing for 10 years, resigned. In the literature, it is partly explained by Bethlen's conviction that the alliance formed by him in the early $1920 \mathrm{~s}$ was stumbling and he therefore did not want to attempt to implement the unpopular crisis treatment measures that were to follow. Bethlen intended to resign only temporarily, while an interim government would take the strictest constringency measures, and then he intended to come back to power. An interim government led by Count Gyula Károlyi was formed in 1931. In the next year, in connection with the shift to the right in international political life and the Hungarian revisionist projects, Gyula Gömbös was appointed Prime Minister by Regent Horthy on 29 September $1932 .{ }^{20}$

crops tickets (bolettas). It was worth 3 pengö (Hungarian currency at that time) per $100 \mathrm{~kg}$, and the sum had to be paid to the producer. A separate fund was established to carry out the payments which were financed by the state.

17 L. Püski, op. cit., pp. 115-122.

18 On 12 October 1930, in the town of Békés, representatives of eleven counties founded the Independent Smallholders' Party with Bálint Szijj as its leader. Two months later, the party merged with Gaszton Gaál's Agrarian Party and was renamed to the Independent Smallholders, Agrarian Workers and Civic Party (commonly known as the Independent Smallholders' Party).

19 The Christian Economic and Social Party, as well as the Hungarian Social Democratic Party and the liberal parties (National Liberal Party, National Democratic Party) retained their former positions. It was the time when the new opposition party, the Independent Smallholders' Party, first appeared in the Parliament, gaining 10 seats; L. Kontler, op. cit., pp. 363-364.

${ }^{20}$ I. Romsics, Bethlen István. Politikai életrajz, Budapest, 1999, $2^{\text {nd }}$ ed., pp. 338-341. 


\section{The idea of 'Christian Agriculture', as an alternative way out of the Great Crisis}

Gömbös was the Prime Minister of Hungary from 1932 until he died in 1936. First of all, it has to be mentioned that he did not come from the aristocracy, which was an important novelty in Hungarian politics. He became a politician after a military career, and gained a seat in the Parliament as a representative of the United Agrarian Laborers' and Smallholders' Party in 1920; he then served as deputy leader of the United Party, which was created by the merger of the Smallholders' Party and the governing party. In 1924 he confronted Prime Minister István Bethlen on several important issues, and together with some fellow politicians (Endre Bajcsy-Zsilinszky, Tibor Eckhardt and others) he founded the Hungarian National Independence Party (Magyar Nemzeti Függetlenségi Párt) - also called the Racial Defense Party (Fajvédó Párt) - which became the right wing opposition to the Bethlen government. In their manifesto there were some anti-Semitic elements. They also remained in close contact with the German right wing extremist movements. ${ }^{21}$ In the economic prosperity of the second half of the 1920s, they lost some of their support, therefore in 1928 Gömbös dissolved his party and re-entered the governing party, where he was soon appointed Minister of Defense. ${ }^{22}$

As has been mentioned above, faced with the inadequacy of the problem solving methods applied so far, there was a growing need for 'hands-on' politics, and in 1932 Gömbös was asked to form a government by the regent of Hungary. His acquaintance with Horthy went back to the chaotic times at the end of World War I. Gömbös played an important role in organizing the National Army led by Horthy.

The Gömbös government was appointed on 1 October 1932. In Hungary, he was the first political leader to introduce himself on the radio. After that, he went on a tour around the country to popularize his slogans (national unity) and his program (the National Work Plan). Accordingly, he changed the name of the governing party to the Party of National Unity. ${ }^{23}$

${ }^{21}$ M. Pittaway, "Hungary," in: The Oxford Handbook of Fascism, ed. R.J.B. Bosworth, Oxford and New York, 2009, pp. 380-397.

${ }^{22}$ See more on Gömbös's political career: J. Vonyó, Gömbös Gyula, Budapest, 2014, pp. 123-140.

${ }^{23}$ J. Gergely, P. Pritz, A trianoni Magyarország, 1918-1945, Budapest, 1998, p. 182 . 
He made his inauguration speech in the Parliament on 11 October, introducing the main points of his program. ${ }^{24}$ His government manifesto containing 95 points was even published, which was also a new idea. The introductory speech of Gömbös in the Parliament has been analyzed in the literature from many points of view. The present paper focuses on how he interpreted the agrarian depression and what message he sought to convey to various groups of agrarian producers.

In his speech, Gömbös mentioned that his most important task was to address the Great Depression. He emphasized that the crisis was especially deep in this region, as the well-established division of work within the Austro-Hungarian Monarchy had been terminated after World War I. According to Gömbös, the economy should respond to the crisis by reducing the production level that had run high during the Great War and by the economic cooperation of self-sufficient states to an extent which was in accordance with their political cooperation. He also mentioned that foreign markets should be gained and that export should be harmonized, as agricultural export cannot be separated from the export of industrial products. It did not seem to be an easy task, as economic reason was overridden by the political divisions in the region resulting from the tension between the new successor states and Hungary, which sought a revision of the peace treaty. Before moving on to discuss solutions for individual areas of the economy, Gömbös made it clear that it would be necessary to create a unanimous agreement in the national public opinion, which would look at individual tasks or problems from a national point of view. ${ }^{25}$ In his speech, Gömbös emphasized the issues of land policy and the necessary solution to the problem of indebted smallholders. The latter was described by him in the following way: "settling people down is a thought of the highest importance at the national level as it keeps the nation alive." ${ }^{26} \mathrm{He}$ integrated into the government program what he had already voiced back in the 1920s: without upgrading the conditions of peasants no adequate army of Hungary could be formed to achieve its revisionist aims when the time came. ${ }^{27}$

${ }^{24}$ The two-chamber legislative system also meant that the Prime Minister was to defend his programme both in the Upper House and in the Lower House (House of Representatives); for shortage of space I do not intend to discuss the comments made in the Upper House.

${ }^{25}$ A Képviselóház 118. ülése [Session 118 of the House of Representatives], pp. 51-53.

${ }^{26}$ Ibid., p. 58.

${ }_{27}$ M. Zeidler, Ideas on Territorial Revision in Hungary, 1920-1945, New York, 2007, pp. 32-48. 
It was hard to find any fault with such an introductory speech of the Prime Minister, as in the area of foreign affairs he openly adopted the revisionist aims, and he concomitantly made a promise to launch a land reform, admitting to the fact that the issue had not yet been solved. It was a topic on which all the opposition parties had already agreed. Now, the Prime Minister himself adopted the claim of the opposition. It was not surprising, as Gömbös had earlier expressed harsh criticism of the 1920 land reform. He pointed out that the governing conservative elite were making eloquent speeches on the role peasantry played in sustaining the nation, but they were not willing to divide their land property to mitigate social tensions. So the idea of 'Christian agriculture' had already begun to take shape back in those days.

Knowing this, it is not surprising if I conclude that there was no other alternative for the opposition but to agree with the Prime Minister and perhaps to call him to account for concrete results. This is the point which connects different speeches made by opposition politicians. There was another recurring element: most of them claimed that the Prime Minister promised too much without having the necessary financial basis at his disposal. This was the opening argument of the speaker of the pro-governmental opposition party (Christian Economic and Social Party). Béla Turi made an ironic remark: "if I were a child, then hearing and seeing this nice program I could wonder at it as much as a child takes pleasure in watching a Christmas tree. [...] But however pleasant it would be for me to describe the ornaments and the beauty of this Christmas tree [...] it is also necessary for me [...] to criticize it." ${ }^{28}$ Turi expressed himself like this as his party and he himself thought that the program contained only generalities and had too broad of a scope. As he put it: "perhaps a little less would be more." 29 Turi praised the Settlement Program,${ }^{30}$ but he did not agree with the refusal to implement unemployment benefits, claiming that half of the 700,000 agricultural workers in Hungary were unemployed, and the 840,000 smallholders were also in a bad financial situation; therefore, he was curious of the details of the promised increase in employment. ${ }^{31}$

The 'youngest' opposition party - the Independent Smallholders' Party, formed in December 1930 - deserves special attention as it was created at the brink of the agrarian crisis, in the aftermath of a number

\footnotetext{
${ }^{28}$ A Képviselóház 118 ülése..., pp. 62-63.

${ }_{29}$ Ibid., p. 65.

30 Ibid., p. 64.

${ }^{31}$ Ibid., p. 65.
} 
of dissatisfied representatives leaving the governing party. The spokesman of the party, Gaszton Gaál, emphasized that as they had their own plans, they would not support the work of the government completely or at all. Concerning the National Work Plan as a whole, he also claimed that it was missing concrete elements. He went even further, describing the government's program in the following way: "It was nice, it was uplifting and carried us away in many respects, but practically they were only words and not concrete things." ${ }^{2}$ Gaál also discussed taxation, saying that Hungarian peasants were no longer able to pay the taxes imposed on them as their crops could only be sold at a low price. He also argued that impending debts should be paid and to achieve this, he deemed it necessary to introduce a general moratorium. Furthermore, he went on, if Gömbös's ideas were centered around peasantry, then proper policies should be developed in terms of taxation, credits, customs and shipping, accordingly. ${ }^{33}$

Although it is not closely connected to our topic, it can be noted that a number of independent representatives touched upon the issue of suffrage, many of them arguing for introducing general and secret voting (ballot). This is important to note as due to the pressure of the Allied Powers, widespread and democratic voting was introduced in Hungary in 1920, which was considerably curbed by István Bethlen's government in 1922 . The decision of the authorities mostly affected the countryside by bringing back open voting again in villages. ${ }^{34}$

In discussing the dispute over the government's program I consider it important to mention the response of another party, mainly because the politician who spoke as its representative, Endre Bajcsy-Zsilinszky, was a fellow of Gömbös in the right wing extremist Racial Defense Party in the 1920s. However, when Gömbös returned to the governing party, he did not follow suit. ${ }^{35}$ It is interesting to note that as a journalist he was a member of the Hungarian Mickiewicz Association, which aimed to cultivate the Hungarian-Polish relations, mainly focusing on literature. During the Depression, Endre Bajcsy-Zsilinszky established an independent party: the Hungarian National Radical Party.

${ }^{32}$ Ibid., p. 68.

${ }^{33}$ Ibid., pp. 70-72.

${ }^{34}$ The new electoral law adopted in 1922 lowered the proportion of voters from about $40 \%$ to $28 \%$. Worse still, without parallel in contemporary Europe, voting was made public everywhere apart from the capital and seven other urban centres, which meant that only one in five of the deputies was elected in secret ballot; I. Romsics, Hungary..., pp. 182-183.

35 J. Vonyó, Gömbös Gyula és a jobboldali radikalizmus, Pécs, 2001. 
In his clearly professional political comment, Endre Bajcsy-Zsilinszky mentioned the agrarian issue several times. He explained that he and his party believed that the pillar of the reforms should be a settlement campaign on a much larger scale than the planned one. He went as far as to say that "we won't overlook the irrevocable historical sins of the latifundium." ${ }^{36}$ According to Bajcsy-Zsilinszky, a large-scale land reform should have been introduced in 1920, but as it was not carried out the one that was implemented he described as inadequate and constituting a mock land reform - now "only a fast and large-scale land reform and settlement can help." He asked for three million katasztrális hold ${ }^{37}$ of land to be divided and those without means and smallholders to be the beneficiaries; he also considered it necessary to strengthen both the hundreds of thousands of smallholders and middle-sized estates. Bajcsy-Zsilinszky also mentioned the cultural and economic advantages of agricultural cooperatives and the possibilities of smallscale and big factories providing employment in the 1,000-1,500 villages to be built after the settlement and the comprehensive consolidation of debts on lands. ${ }^{38}$

In his first interview after his introductory speech in the Parliament, Gömbös responded to the fact that the MPs were demanding a detailed elaboration of the government program. "In the National Work Plan, directives have been laid down. The directives contain no concrete instructions on the execution of the plan. Measures concerning practical solutions will be taken by the responsible ministers, according to the points of the National Work Plan. It is possible that achieving a point may require several decrees or legislative measures, perhaps as many as ten. The principles have been laid down in the National Work Plan, it is the task of the responsible ministers to adopt them and to precisely execute them." ${ }^{39}$

The National Work Plan received widespread media coverage in the daily press. For lack of space, this paper can cover only its small segment. I chose the daily paper that was mainly read by agricultural laborers. The newspaper called Új Barázda [New Furrow] dealt with the National Work Plan two times, first on 27 October 1932, and for the second time in its subsequent issue on 30 October. The first article was written in an elevated style full of metaphors, the title already calling

${ }^{36}$ A Képviselóház 119. ülése [Session 119 of the House of Representatives], p. 108.

${ }^{37}$ Hungarian unit of land measurement, 1 katasztrális hold $(\mathrm{kh})=0,57$ hectare (ha) of land.

38 A Képviselóház 119. ülése..., p. 109.

${ }^{39}$ Budapesti Hírlap, 27 October 1932, no. 242, p. 1. 
Gömbös a torch carrier. The article, written by an ex-Smallholders' Party minister, approached the government program with symbolism. It highlighted that it was "coping with the mental crisis." ${ }^{40}$ According to the author, this crisis derived from the damages caused by Great Depression, and he defined it as an illness to be treated, but the treatment could be hindered by a number of problems. When describing the issues, the article once again became full of metaphors, with troubles appearing as "snakes hiding under lichen," the nation living its life as a "cell-system," and "the spoilers of national spirit" resorting to "intoxicating means" to achieve their aims. The author thought that the first 'lap' in the struggle to cope with the crisis had been successful, "the mere appearance of Gyula Gömbös at the helm of the nation has induced faith and trust in the minds of those prone to become disheartened." According to the final lines of the text, Gömbös would be that strong-handed helmsman who manages to steer the boat of the country from the stormy sea to the shore. The sea represented the economic war sent against the nation by fate. The author asked the readers for patience and support for the work of the government and the Prime Minister. "Let us follow Gyula Gömbös, the torch carrier with a bosom filled with hope in the Hungarian night." ${ }^{41}$

\section{The results and limits}

The chapter on agriculture can be considered the most elaborate section of the National Work Plan. ${ }^{42}$ As has already been mentioned, the concept of 'Christian agriculture' had already been a central element of the program of Gömbös and his party in the 1920s. ${ }^{43}$ Even then, they emphasized that they considered the Christian idea to be not religious but racial, one that serves the interests of the nation. The farming population - the peasants - were considered to be the main guardians of Hungarian values. By defining them as such, Gömbös and his followers opposed liberalism. They rejected liberal ideas in the realms of economy, politics and culture, as they blamed them for the heavy losses Hungary had to sustain.

\footnotetext{
${ }^{40}$ I. Szabó, "Kövessük a fáklyavívôt,” Új Barázda, 27 October 1932, no. 135, p. 1.

${ }^{41}$ Ibid.

42 J. Gergely, F. Glatz, F. Pölöskei, Magyarországi pártprogramok, 1919-1944, Budapest, 2003, pp. 288-302.

${ }^{43}$ J. Vonyó, Gömbös Gyula, pp. 123-140.
} 
The question may arise why it was necessary to emphasize Christian agriculture when in the 1920s the governing party considered itself to be Christian-nationalist. As has been mentioned above, Gömbös saw it as the main problem that the government led by Bethlen would give eloquent speeches in appreciation of the role of the mainly Catholic peasantry in the recovery of the nation after Trianon, but its policy remained at the level of propaganda, and no practical measures were taken. The official stance was that peasants were living in poor conditions, but were satisfied with their fate. The long lasting crisis gave the lie to those claims and more and more reports were informing of the signs of a mental crisis reaching beyond the economic and social problems. These included the spread of sects in the countryside or the fact that village communities overlooked the murders of children so that they would not have to divide the land among the heirs. The high unemployment rate triggered the starvation of children and the spread of consumption. ${ }^{44}$ At first, it was the leftist young intelligentsia who wrote about it, but the right wing could not overlook it either. ${ }^{45}$

Gömbös and his followers aligned mainstream economic and social policies with the traditionally agrarian character of the nation, similarly to their views back in the 1920s. Apart from the fact that a whole chapter of the National Work Program, namely Chapter VI (points 46-54), was dedicated to the issues of agriculture and land policy, numerous other points in the government's manifesto contained references to the high importance of this sector of the economy. Point 38 in the National Work Program made it clear that the government held it as one of its priorities to develop the branches of production which provided livelihood to a large number of people. ${ }^{46}$ Chapter VII, dedicated to industrial policy, began in the following way: "However, our support of industry cannot hinder any other segment of production." ${ }^{47}$ Knowing the economic situation in Hungary at that time and the economic-political views of Gömbös and his followers, this "other segment of production" could be nothing else but agriculture. It is underlined

${ }^{44}$ P. Gunst, "Hungarian Agrarian Society during the Inter-War Period (1919-1945)," in: Hungarian Agrarian Society from the Emancipation of Serfs (1848) to the Re-Privatisation of Land, ed. P. Gunst, New York, 1998, pp. 199-253; G. Gyáni, "Social History of Hungary in the Horthy Era," in: Social History of Hungary from the Reform Era to the End of the Twentieth Century, eds. G. Gyáni, G. Kövér, T. Valuch, New York, 2004, pp. 271-507.

45 D. Némedi, A népi szociográfia 1930-1938, Budapest, 1985.

${ }_{46}$ Point 38 in: J. Gergely, F. Glatz, F. Pölöskei, op. cit., p. 294.

${ }^{47}$ Point 55 in: ibid., p. 296. 
by the fact that their industrial development policy intended to support those industries that "processed inland raw materials and agricultural produce." 48 A separate point was dedicated to the development of cottage industry, which "satisfied the needs of village people and used their workforce." ${ }^{49}$ By providing "fair prices" for industrial products, the party aimed to eliminate or at least to reduce the price scissors of industrial-agricultural products, which were a bane of the agrarian sector. ${ }^{50}$ Similar intentions are reflected in Chapters VIII and IX on commercial and credit policies. ${ }^{51}$

The main points of Chapter VI were the following ones: improving the agricultural export and the ability of agriculture to provide industry with raw materials by reorganizing its branches; reducing the number of various crops and equalizing their quality; carrying out the settlement program - observing the national interests and avoiding any decline in the production; creating a land basis for the settlement; reorganizing the entail system and extending it to smallholders and middle-sized estates; supporting the work of cooperatives - in loaning, farming, consumption, production and selling.

Having defined the goals of the government, we can go on to discuss how they were implemented, which will make it conspicuous how limited were the actual measures taken by the authorities. The continually significant influence of the aristocracy restricted the attempts to find a way out of the pressing economic crisis. As József Vonyó put it appropriately: "As the head of the government, the prisoner of the governing party" - this was the title he gave to the chapter analyzing the early period of the Gömbös government. ${ }^{52}$ It was a heavy burden on Gömbös at the start that "he had to start governing with a power and party elite who restricted the achievement of their political aims rather than supporting them." ${ }^{53}$

This may explain why there were two stages in the execution of the agrarian policy of the Gömbös government. The first stage lasted

${ }^{48}$ Point 56 in: ibid.

${ }^{49}$ Point 58 in: ibid.

50 Point 59 in: ibid., p. 296-297.

${ }^{51}$ It has to be mentioned that Chapter IV on the current tasks of law seemed to be in harmony with all these. For instance, the acts of "economic credit law and criminal law" were to be reformed in a way that would take into consideration "the moral and economic characteristics of the Hungarian nation to a full extent." It was supported by the promise of an effective protection of rights for the productive work adapted to the interests of the nation; ibid., pp. 292-293.

${ }^{52}$ J. Vonyó, Gömbös Gyula, pp. 166-171.

${ }^{53}$ Ibid., p. 169. 
until 1934/35, and consisted in continuing the crisis management policy of the Bethlen government: state support for the sale of crops abroad. The Gömbös government made great efforts to find new markets for the excess agricultural produce of Hungary. It hoped to reduce the negative balance of external trade and to improve the balance of the state budget. The first complementary agreement of the German-Hungarian commercial treaty in 1933, followed by a second complementary agreement signed a year later and the economic agreements with Austria and Italy signed in March 1934 as part of the Rome Protocols, reduced the problems in the export of Hungarian agricultural produce and, in the long term, they fully eliminated them. ${ }^{54}$ As a result, the balance of external trade turned positive again in 1933, and signs of recovery began to show since the economic year 1934/35.

The other principal objective of the Gömbös government's crisis management measures was to protect small farms. A serious result of the chronic agrarian crisis was the fact that even in 1933 tens of thousands of peasant farms were auctioned off. ${ }^{55}$ During the time of the Gömbös government, in 1933 and 1935, laws were passed to finance the repayment of farmers' debts. According to these acts, the plots where the debts reached a critical limit were declared to be protected upon the request of the debtor, and they were registered. These plots were not to be auctioned off if the owner had paid the interests on the loan. The state allocated considerable sums to pay off "smallholders' debts." 56

Nevertheless, these measures only focused on the treatment of the superficial signs of the crisis. Gömbös was only able to implement the program of Christian agriculture, which aimed to achieve further reaching goals, when his followers became members of the governing party after the 1935 elections. It is telling that István Bethlen together with 13 of his fellow conservative politicians left the governing party before the elections and ran as an independent candidate. ${ }^{57}$

${ }^{54}$ M. Szuhay, "Evolution of Hungarian Agriculture during the Inter-War Years (1918-1945)," in: Hungarian Agrarian Society from the Emancipation of Serfs (1848) to the Re-Privatization of Land (1998), ed P. Gunst, New York, 1998, pp. 182-185.

55 Ibid., pp. 177-190.

${ }^{56}$ In the budget years of 1933/34 and 1934/35, 32.5 million pengó (Hungarian currency at that time) were allocated to such purposes, and in the years 1935/36$-1936 / 37$ - 75.6 million pengó. It is important to note that most subventions accompanying the protection were given to middle size and large land owners as $61 \%$ of the 1.9 million $\mathrm{kh}$ (some 1 million ha) of protected land fell in the category of plots bigger than $100 \mathrm{kh}$ (57.5 ha).

${ }^{57}$ I. Romsics, Hungary..., p. 184. 
At first, due to the expected resistance of the aristocracy, a project was set up to help land consolidation. Peasant farming was hindered by the fact that due to the system of inheritance, the lands that belonged to each farm were scattered. The magnitude of the problem is exemplified by the fact that in the mid-1930s, there were $14,800,000$ parcels and $2,100,000$ owners on $8,600,000 \mathrm{kh}$ (nearly 5 million ha) of land, so on average, a smallholder's $4 \mathrm{kh}$ (2.4 ha) of land were scattered in seven parts. ${ }^{58}$ The issue of scattered plots would have been helped by land consolidation, namely a process regulating land property in which the scattered parcels of particular farmers within the territory of a town or village were merged into one or more parcels, but considerably fewer than earlier, by way of a legal forum and with the consent of the proprietors. The main aim of the new decrees was to make regulated land consolidation more simple, faster, more professional and cheaper. In 1936, the process gained momentum again. On the one hand, it facilitated the conclusion of the land consolidation initiatives started in the previous years and on the other, owing to the greater role played by the state, it was also possible to carry out the process elsewhere. ${ }^{59}$

The government's aims in terms of its land policy were set in Acts XI and XXVII adopted in 1936. Act XI of 1936 provided for family entailment and entailed smallholdings. The latter regulation was a real novelty, as the Prime Minister wanted to help create peasant farms which would not run the risk of being divided. Whereas Gömbös considered Mussolini's Italy as an example, in this respect he learnt from the agrarian policy of Nazi Germany. When defining who could own such small holdings, the government adopted the German model, namely Darré's law on succession (Reichserbhofgesetz, 1933), as the legal base. ${ }^{60}$ The act on settlements was passed on 16 June 1936 (1936: Act XXVII); it aimed to redistribute 400,000 $\mathrm{kh}$ (some 240,000 ha) of land over the following 25 years. All this clearly shows that the aristocracy managed

\footnotetext{
58 J. Sipos, op. cit, pp. 109-120.

59 According to the data given by Department of Land Consolidation of the Ministry of Agriculture, in 1936 the process of land consolidation began in 24 villages, in 1937 in 18, in 1938 in 15, and in 1939 in 20 villages - altogether in 77 villages. All in all, between 1935-1941, the procedure of land consolidation was completed in 98 villages on a total area of $310.507 \mathrm{kh}$. Magyar Nemzeti Levéltár Országos Levéltár [National Archives of Hungary, hereafter MNL OL] FM K-184, 1941, fol. 5699.

${ }^{60}$ G. Corni, H. Gies, "Blut und Boden": Rassenideologie und Agrarpolitik im Staat Hitlers, Idstein, 1994, pp. 103-128; G. Gerhard, "The Modernization Dilemma: Agrarian Policies in Nazi Germany," in: Agriculture in the Age of Fascism. Authoritarian Technocracy and Rural Modernization, 1922-1945, eds. F. Prieto, J. Pan-Montojo, M. Cabo, Turnhout, 2014, pp. 139-158.
} 
to prevent the introduction of real land reform again. It was useless for the Gömbös government to help the new land owners with a complex program (such as loans or consultations), the area affected by the land reforms was so small that the basic problems of agrarian society remained unsolved. Gömbös, who was seriously ill at the time, could not achieve any more.

\section{Conclusions}

The concept of Christian agriculture was developed in the 1920s by Gömbös and his followers, with their initiative mainly focused on the long-term goal of enlisting peasants into the army which they needed to achieve their revisionist objectives. It was during the Great Depression when the time had come to bring this concept to life. From the very beginning, it focused mainly on land reform, but as Gömbös created a government during the Depression, the concept of Christian agriculture was complemented by some additional elements. All of them were expressed in the National Work Plan, although some were not described in detail but merely referenced. The development of vocational education and strengthening the position of cooperatives were among the new elements.

These are worth mentioning, as they involved measures with much further reaching effects than were necessary to treat the results of the overproduction crisis. These modernization policies were developed by the Gömbös government to remedy the structural crisis. The obstinate opposition of the aristocracy prevented not only the redistribution of land by the state, but it also affected how the other elements of the program were carried out. As a result, the structural problems that burdened Hungarian agriculture at the beginning of the $20^{\text {th }}$ century were still current issues half a century later, at the end of World War II. ${ }^{61}$ This economic and social heritage had far reaching effects on the development of the Hungarian society after 1945, resulting in the disappearance of the aristocracy... and in the exclusion of many peasants from the health care system until the early 1960 s. ${ }^{62}$ In some respects, its

${ }^{61}$ Zs. Varga, "Challenges and Responses: Dilemmas of the Agrarian Modernization in Interwar Hungary," in: Agriculture in the Age of Fascism. Authoritarian Technocracy and Rural Modernization, 1922-1945, ed. F. Prieto, J. Pan-Montojo, M. Cabo, Turnhout, 2014, pp. 113-138.

${ }^{62}$ B. Tomka, Social Security in Hungary in a Long-run and Comparative Perspective: Expenditures, Social Rights, and Organization, 1918-1990, Berlin, 2002. 
traces could even be detected after the change of the political system (e. g. the representation of agricultural interests), which may serve as food for thought on the power of path dependency.

\section{Bibliography}

Berend I.T., Decades of Crisis: Central and Eastern Europe before World War II, Berkeley, 1998.

Berend I.T., Ránki G., Economic Development in East-Central Europe in the $19^{\text {th }}$ and $20^{\text {th }}$ Centuries, New York and London, 1974.

Berend I.T., Ránki G., "The Economic Problems of the Danube Region after the Breakup of the Austro-Hungarian Monarchy," in: Trianon and East Central Europe. Antecedents and Repercussions, eds. B.K. Király, L. Veszprémy, New York, 1995, pp. 149-163.

Brassley P., "Land Reform and Reallocation in Interwar Europe," in: Contexts of Property in Europe. The Social Embeddedness of Property Rights in Land in Historical Perspective, eds. R. Congost, R. Santos, Turnhout, 2010, pp. $145-164$.

Corni G., Gies H., "Blut und Boden": Rassenideologie und Agrarpolitik im Staat Hitlers, Idstein, 1994.

Crampton R.J., Eastern Europe in the Twentieth Century and After, London, 1997.

Gergely J., Glatz F., Pölöskei F., Magyarországi pártprogramok, 1919-1944, Budapest, 2003.

Gergely J., Pritz P., A trianoni Magyarország, 1918-1945, Budapest, 1998.

Gömbös Gyula válogatott politikai beszédek és, ed. J. Vonyó, Budapest, 2004.

Gunst P., "Hungarian Agrarian Society during the Inter-War Period (1919-1945)," in: Hungarian Agrarian Society from the Emancipation of Serfs (1848) to the Re-Privatization of Land (1998), ed. P. Gunst, New York, 1998, pp. 199-253.

Gunst P., "Hungarian Agriculture between 1919 and 1945," in: History of Hungarian Agriculture and Rural Life, 1848-2004, ed. J. Estók, Budapest, 2004, pp. 137-219.

Gyáni G., "Social History of Hungary in the Horthy Era," in: Social History of Hungary from the Reform Era to the End of the Twentieth Century, eds. G. Gyáni, G. Kövér, T. Valuch, New York, 2004, pp. 271-507.

Held J., "The Interwar Years and Agrarian Change," in: The Modernization of Agriculture: Rural Transformation in Hungary, 1848-1975, New York, 1980.

Kontler L., A History of Hungary, New York, 2002.

Kopsidis M., "Agricultural Development and Impeded Growth: The Case of Hungary, 1870-1973," in: Agriculture and Economic Development in Europe since 1870, eds. P. Lains, V. Pinilla, London and New York, 2009, pp. 286-310. 
Némedi D., A népi szociográfia 1930-1938, Budapest, 1985.

Orosz I., "Peasant Emancipation and After-effects," in: Hungarian Agrarian Society from the Emancipation of Serfs (1848) to the Re-Privatization of Land (1998), ed. P. Gunst, New York, 1998, pp. 53-97.

Pittaway M., "Hungary," in: The Oxford Handbook of Fascism, ed. R.J.B. Bosworth, Oxford and New York, 2009, pp. 380-397.

Pogány Á., “A nagy válság nagy magyarázatai. Az 1930-as évek gazdasági válsága az újabb szakirodalom tükrében," Korall 14, 2013, no. 54, pp. 153-174.

Püski L., “Az agrárkérdés a harmincas évek Magyarországán nagybirtokos nézôpontból," in: Politika, gazdaság és társadalom a XX. századi magyar történelemben, eds. L. Püski, L. Timár, T. Valuch, Debrecen, 1999, pp. 115-122.

Romsics I., Hungary in the Twentieth Century, Budapest, 1999.

Romsics I., Bethlen István. Politikai életrajz, Budapest, 1999, $2^{\text {nd }}$ ed.

Sipos J., "A földkérdés," in: Gróf Bethlen István és kora, ed. I. Romsics, Budapest, 2014, pp. 109-120.

Szuhay M., "Evolution of Hungarian Agriculture during the Inter-War Years (1918-1945)," in: Hungarian Agrarian Society from the Emancipation of Serfs (1848) to the Re-Privatization of Land (1998), ed. P. Gunst, New York, 1998, pp. 177-190.

Tomka B., Social Security in Hungary in a Long-Run and Comparative Perspective: Expenditures, Social Rights, and Organization, 1918-1990, Berlin, 2002.

Varga Zs., "Challenges and Responses: Dilemmas of the Agrarian Modernization in Interwar Hungary," in: Agriculture in the Age of Fascism. Authoritarian Technocracy and Rural Modernization, 1922-1945, eds. L. Prieto, J. Pan-Montojo, M. Cabo, Turnhout, 2014, pp. 113-138.

Vonyó J., Gömbös Gyula és a jobboldali radikalizmus, Pécs, 2001.

Vonyó J., Gömbös Gyula, Budapest, 2014.

Zeidler M., Ideas on Territorial Revision in Hungary, 1920-1945, New York, 2007.

Tibor Tóth

Lessons from the Great Depression in Hungary. The idea of 'Christian Agriculture' and its limits (Summary)

In Hungary, the effects of the Great Depression were the most serious and long lasting in the agrarian sector. In the Hungarian political life various groups had different opinions on the causes of the Depression and the possible methods to eliminate it. In connection with the shift to the right in international political life and the Hungarian revisionist projects, in 1932 Gyula Gömbös was appointed Prime Minister by Regent Horthy. Gömbös and his 
supporters, including the gentry, military officers and state officials, had already announced back in the 1920s that the borderlines drawn up in the Trianon Peace Treaty could only be modified in arms. It required an army, and the army could be based on peasantry, but peasants should first be made strong and independent in terms of their morals and finances so that they could live up to the expectations they were to face. Therefore, the economicpolitical views of Gömbös and his followers focused on the idea of 'Christian agriculture,' which meant, according to them, that the economy of Hungary should be reorganized in an agrarian way as the Hungarians who keep the nation alive are the peasants. The present study tries to give an overview of the main elements of the reform program of the Gömbös government (1932-36). Moreover, it also seeks to analyze how it was viewed by the various political parties. For this purpose, minutes from parliament sessions and contemporary press releases have been used. Finally, an overview is given of the goals the Gömbös government managed to achieve.

Tibor Tóth - Workplace: National Disability and Social Politics Centre (www.fszk.hu).

E-mail: dr.toth.tibor.74@gmail.com. 